\title{
Analysis of Cooperative Financial Performance in Ibadan Metropolis, Oyo State, Nigeria
}

\author{
R. Kassali ${ }^{1 *}$, A. O. Adejobi ${ }^{1}$ and C. P. Okparaocha ${ }^{2}$ \\ ${ }^{l}$ Department of Agricultural Economics, Obafemi Awolowo University, Ile-ife, Osun State, Nigeria \\ ${ }^{2}$ Nigerian Tribune, Lagos, Nigeria
}

\begin{abstract}
This study examined the financial performance of agricultural cooperative societies in Ibadan Metropolis, Oyo State; this as a way of ensuring impact on members and the communities of location. Primary data were collected from thirty (30) cooperatives through interview of principal officers using well structured questionnaire while secondary data were from the cooperatives annual reports. The analytical techniques used include descriptive statistics applied to financial aggregates and ratios and regression analysis. The financial aggregates analysed include current assets, current liabilities, cash and account receivable, and owners' equity. The financial ratios were current ratio, acid test, equity to assets, debt to equity, debt to assets and current debt to equity. Cooperative's structural and financial elements were hypothesized as determinants of cooperative financial performance. All variables except cooperative size had significant effect on financial performance. But years of operation, and number of loans beneficiaries only had negative effect on performance. The study concluded on appropriate measures needed to improve cooperative financial performance.
\end{abstract}

Keywords: Nigeria, cooperative, financial ratios, financial performance index

\section{Introduction}

A Cooperative can be defined as a social enterprise or organization created voluntarily by members with the full support and assistance from members in order to cater for the economic needs and interests of the members. The idea was to pull members economic forces together to ease their access to finance and other socio-economic resources. The basis instituting a cooperative organization includes common business interest, location, professional goals and objectives, need for social interaction on common interest, exploitation of common resources through group strategy.

A good cooperative system could be very useful and instrumental to the development and progress of any society. The simplest and most basic benefit of cooperative societies is the creation of an avenue for members to borrow money and obtain loans with minimal interest to meet their business and social needs and serves as an avenue for savings. Circulation and diffusion of various forms of innovation are also made easier through cooperative to stimulate economic growth (Adegeye \& Dittoh, 1985). According to Mellor (1980) and Stevens and Jabara (1998), cooperatives have aided producers in many countries of the world to improve their livelihood. "Ijere (1978) defined cooperative as a business entity that seeks

${ }^{*}$ Corresponding author. to maximise profit to ensure growth of the social enterprise, grow members' business and alleviate poverty of member-shareholders; and unlike an Investor-Owned Firm (IOF) the cooperative society draws its capital base from the contribution of members or through credit from banks. It is characterized by democratic control, equal vote and equal participation to the management of the organization, a low and un-exploitative interest rate assuming conditions for growth and capital accumulation for the benefit of members; doing away with IOF exploitative tendencies." But cooperative like IOF uses same financial management tools to perform efficiently their functions to member-patrons and one of the goals of a cooperative society is to ensure financial stability of members (Ijere, 1978). It is a powerful instrument that ensures that loans are adequately and timely available to members. Profit from cooperative are used like in IOF to repay loans, ensure society growth or redistributed in form of dividend to members. Same tools used in IOF such as balance sheet, profit and loss account, cash-flow statement and financing plan apply also to cooperative financial analysis and forecasts including various financial ratios (Ijere, op. cit).

\section{Literature Review}

Adesina (1998) defined a cooperative society as an organization where people voluntarily associate 
together on the basis of equality having equal participation in management to promote common economic interests, using equal voice, making approximately equal or proportional contributions to capital and deriving proportional services and benefits from it and run for those who use its services.

Roy (1981) noted that one of the most important features of a successful cooperative enterprise is a sound accounting system which does not differ greatly from profit type firms and financial ratios used in evaluating a business firm's performance are valuable tools for measuring the strengths and weaknesses of a cooperative enterprise. This involves keeping an accurate record of each member-patron's purchases and sales through the cooperative. A monthly balance sheet and operating statement are usually required and the amount by which assets exceed liabilities is shown as member's equity in the balance sheet.

The projected financial statements for an enterprise offers the financial analyst the ability to calculate financial ratios that allow him to form judgment about the efficiency of the enterprise, its return on key aggregates, its credit worthiness and solvency (Gittinger, 1992).

Financial ratios can be analysed using three parameters: efficiency ratios, Income ratios, and credit worthiness ratios ( Roy, 1981; Gittinger, 1992). Efficiency ratios enable analyst to form a judgment about the efficiency in assets use and allow expense control of an enterprise. Efficiency ratios include: (i) Inventory turnover which is the measure of the number of times that an enterprise turns over its stock each year and indicates the level of inventory needed to support a given level of sales. A low ratio means that large stocks must be held to ensure that production schedule is met and high turnover indicates that the enterprise is able to recover its inventory investment rapidly and that there is a good demand for its product or services. (ii) The operating ratio which is obtained by dividing the operating expense by the operating costs. This is most useful when operations of the same enterprise are compared year by year or when the enterprise is compared with similar industries. (iii)Income ratio: This shows the long term financial ability of an enterprise to generate funds for reinvestment and growth and to provide satisfactory return on investment. Income ratios include return on sales, return on equity, and returns on assets. (iv) Credit worthiness ratio: this enables judgment about the degree of financial risk inherent in the enterprise before undertaking a project. It shows what financing the project will need and the suitable terms. Credit ratio is measured by the current ratio and the debt-equity ratio. The current ratio which is the current assets divided by the current liabilities is an indication of the margin that the enterprise has for its current assets to shrink in value before it faces difficulty in meeting its current obligation. According to Gittinger, an important financial ratio for credit agencies is the debt-equity ratio which is found to be a good guide against "losses".

Another tool in financial performance analyses is the Balance Sheet. According to Okeya and Adediran (1996), the balance sheet is a "snapshot" picture of the financial ratio state of an enterprise. That is the statement of the assets and liabilities of a business at a particular date. It enables the management to deliberate on their operational achievement for that year before presentation to the shareholders. From that balance the following ratios can be computed:

- Current ratio: this is the ratio of current assets to current liabilities. The main purpose of this ratio is to measure the short - term solvency and it indicates that the company could readily cover its liabilities adequately through cash generated with its current assets.

- Acid test ratio: The quick ratio or acid test ratio is a specific test of liquidity. It tests whether a business is expecting to realize enough cash from its current assets in the near future to pay off all its current liabilities.

-Equity to assets: This ratio indicates the proportion of the shareholders' stake in the assets of the business, i.e. the ratio of the business' assets financed by the shareholders.

- Debt to Equity: This ratio is important in knowing if the company or the cooperative society has overborrowed or not. A maximum "safe" debt/equity ratio is $50 \%$, which means that one half of the total assets of a business are being externally financed.

Akridge and Hertel (1992) found nonsignificant costs advantages between cooperatives and IOFs dealing in grain and farm supply, using a generalized trans-log cost function. Lerman and Fulton (1990) compared the financial performance of two types of dairy farms between 1976 and 1987 and concluded that cooperatives performed significantly better than IOFs in terms of leverage, liquidity and asset performance.

In Nigeria, one the problems among cooperatives is lack of adequate capital and proper financial management. Adesina (1998) identified poor patronage, overdue loans, over population and the failure to put cooperative education and uphold cooperative principles as major problems of cooperative management in Nigeria. There is also the problem of financial performance records of cooperatives.

Kassali and Adeyemo (2007) found that cooperatives societies operated in a competitive environment and engaged in development and poverty alleviation projects while membership and number of services provided to members were some of the determinants of cooperative performance in Osun State. This study intends to assess the performance of cooperatives as yardstick to evaluate contribution to members' welfare and the 
development of local communities. The objectives of the study were to analyse the structure, financial ratios and the determinants of cooperative financial performance in Ibadan Metropolis.

\section{The Study Area}

This study was carried out in Ibadan, the capital city of Oyo State, a Metropolis located in southwestern Nigeria. Ibadan is a regional commercial hub for both agricultural and industrial goods from different parts of the country. The area is an amalgamation of urban and rural structures characterised by year round booming commercial and social activities with networks of cooperative societies of different sizes, small to large cooperatives, including single and multipurpose types catering for members' welfare based on their professional interests and engaging in development projects for the successful ones besides access to inputs, job creation, trading in shares and stocks, establishment of trading complex, agro-allied inputs delivery, investment in real estate, etc.

\section{Methodology}

\section{Sampling and data collection}

The data were collected from a sample of 30 randomly selected cooperatives that comprised agriculture, marketing, housing, handicraft, credit and savings cooperatives, etc. Interview using a well structured and pre-tested questionnaire helped collecting data on: cooperative's year of establishment, membership status, cooperative management structure and activities, services to members, sources of funds, investment projects carried out, number of employees, loan beneficiaries, training programme, etc.

The questions were addressed to an executive member of the cooperative at least the president while a compilation of cooperative's financial records or annual statements including balance sheet was made. This was completed by information from cooperative annual general meeting reports. The field survey took place within the period of June-July- August of 2007 using a well trained enumerator with all questionnaire duly attempted.

\section{Methods of data analysis}

Descriptive statistics, financial ratios derived from the financial statements including regression technique were used to analyse the data. This study measures the efficiency and financial performance of cooperatives based on the following financial ratios: current ratio (CR), Acid - test, Debt to Assets (D/A), Debt to equity (D/E), Equity to Assets (E/A), owners 'equity to net assets and current debt to equity. A financial performance index is also measured for each cooperative and the determinants of financial performance assessed.

\section{Computation of financial performance index}

The financial performance is a measure of how well a firm utilizes its resources. According to Adegeye and Dittoh (1985), it is an indication of adequacy of financial management of firms. The following formula based on financial ratios is adopted to quantify the financial performance index of cooperative:

$\mathrm{K}_{\mathrm{f}}=\operatorname{Ln}\left(\frac{X 1+X 2+X 3+X 4}{X 5+X 6+X 7}\right)$

Where,

$\mathrm{K}_{\mathrm{f}}=$ Cooperative Financial Performance Index

$\mathrm{X}_{1}=$ Current ratio

$\mathrm{X}_{2}=$ Acid-test

$\mathrm{X}_{3}=$ Equity to assets

$\mathrm{X}_{4}=$ Owners' equity to asset

$\mathrm{X}_{5}=$ Debt to assets

$\mathrm{X}_{6}=$ Debt to equity

$\mathrm{X}_{7}=$ Current debt to equity.

This index expresses degree of overall solvency of cooperative. The higher the index, higher is the cooperative expected performance.

\section{Determinants of financial performance}

Hypothesized cooperative structural elements were used as determinants of cooperative financial performance. The implicit form of the empirical model is as follows:

$\mathrm{K}_{\mathrm{p}}=\mathrm{f}(\mathrm{M}, \beta ;$ ei $) \quad \mathrm{i}=1, \ldots \mathrm{n}$

$\mathrm{M}=$ vector of cooperative structural characteristics

$\beta=$ vector estimation parameters

ei $=$ normally distributed error term

$\mathrm{n}=$ number of observations.

\section{Results and Discussion}

\section{Cooperatives financial characteristics}

Results from Table 1 show that $33 \%$ of cooperatives had current assets above $\$ 5,000,000$ $(\$ 31,847) ; 23 \%$ had it between $\$ 1,000,000$ $2,000,000(\$ 6,369-12,738)$ and $16 \%$ had it between $\$ 3,000,000-4,000,000 \quad(\$ 19,108$ 25,477 ) while $10 \%$ had current assets between $4,000,000-5,000,000(\$ 25,477-31,847)$. Current assets are those assets used within a year, therefore majority of cooperative societies used above $\mathrm{N} 5,000,000(\$ 31,847)$ in running the business. The current liabilities are above 5,000,000 $(\$ 31,847)$ for about $50 \%$ of cooperatives and was between $\$ 4,000,000-5,000,000(\$ 25,477-31,847)$ for $20 \%$ of cooperatives only. This means that cooperatives seem to have more liabilities than assets.

The cash and account receivable was less than $\mathrm{N} 1$ million $(\$ 6,369)$ for $13 \%$ of cooperative, 
between 1-2 million $(\$ 6,369-12,738)$ for $17 \%$; 3 4 million $(\$ 19,108-25,477)$ for $17 \%$ also and $33 \%$ had above 5 million Naira $(\$ 31,847)$. This means that quite a number of cooperatives have huge amount of cash to be recovered for operation. The owner's equity was above 5 million Naira
$(\$ 31,847)$ for $33 \%$ of cooperatives; between $4-5$ million $(\$ 25,477-31,847)$ for $25 \%$ of cooperatives and less than 2 million $(\$ 12,738)$ for about $27 \%$ of cooperative societies. This indicates a good financial stand of most cooperatives for smooth operation.

Table1. Cooperative financial characteristics.

\begin{tabular}{|c|c|c|c|}
\hline Financial characteristics & Range & Frequency & Percentage \\
\hline \multirow{7}{*}{$\begin{array}{l}\text { Cooperatives' current } \\
\text { assets }\end{array}$} & Less than $\$ 1,000,000(\$ 6,369)$ & 03 & 10.00 \\
\hline & $\$ 1,000,001-2,000,000(\$ 6,369-12,738)$ & 07 & 23.30 \\
\hline & N2,000,001-3,000,000 $(12,738-19,108)$ & 02 & 06.70 \\
\hline & \#3,000,001-4,000,000 (\$19,108-25,477) & 05 & 16.70 \\
\hline & $\$ 4,000,000-5,000,000(\$ 25,477-31,847)$ & 03 & 10.00 \\
\hline & Over $\$ 5,000,000(\$ 31,847)$ & 10 & 33.30 \\
\hline & Total & 30 & 100.00 \\
\hline \multirow{7}{*}{$\begin{array}{l}\text { Cooperatives current } \\
\text { liabilities }\end{array}$} & Less than $\$ 1,000,000(\$ 6,369)$ & 02 & 06.70 \\
\hline & $\$ 1,000,001-2,000,000(\$ 6,369-12,738)$ & 05 & 16.70 \\
\hline & $\geqq 2,000,001-3,000,000(12,738-19,108)$ & 02 & 06.70 \\
\hline & \#3,000,001-4,000,000 $(\$ 19,108-25,477)$ & 06 & 20.00 \\
\hline & $¥ 4,000,000-5,000,000(\$ 25,477-31,847)$ & 00 & 00.00 \\
\hline & Over $\$ 5,000,000(\$ 31,847)$ & 15 & 50.00 \\
\hline & Total & 30 & 100.00 \\
\hline \multirow{7}{*}{$\begin{array}{l}\text { Cash and account } \\
\text { receivable by the } \\
\text { cooperatives }\end{array}$} & Less than $¥ 1,000,000(\$ 6,369)$ & 04 & 13.30 \\
\hline & $\$ 1,000,001-2,000,000(\$ 6,369-12,738)$ & 05 & 16.70 \\
\hline & $¥ 2,000,001-3,000,000(12,738-19,108)$ & 02 & 06.70 \\
\hline & \#3,000,001-4,000,000 $(\$ 19,108-25,477)$ & 05 & 16.70 \\
\hline & $\$ 4,000,000-5,000,000(\$ 25,477-31,847)$ & 04 & 13.30 \\
\hline & Over $\$ 5,000,000(\$ 31,847)$ & 10 & 33.30 \\
\hline & Total & 30 & 100.00 \\
\hline \multirow[t]{7}{*}{ Owners' equity } & Less than $¥ 1,000,000(\$ 6,369)$ & 04 & 13.33 \\
\hline & $\$ 1,000,001-2,000,000(\$ 6,369-12,738)$ & 04 & 13.33 \\
\hline & 2 $2,000,001-3,000,000(12,738-19,108)$ & 03 & 10.00 \\
\hline & $¥ 3,000,001-4,000,000(\$ 19,108-25,477)$ & 03 & 10.00 \\
\hline & $¥ 4,000,000-5,000,000(\$ 25,477-31,847)$ & 06 & 20.00 \\
\hline & Over $\$ 5,000,000(\$ 31,847)$ & 10 & 33.33 \\
\hline & Total & 30 & 100.00 \\
\hline
\end{tabular}

$\$ 1=\$ 157$

\section{Analysis of financial ratios}

The current ratio is the ability of firms to face short-term obligations or pay its debts over an exercise period. It was above 15 for $40 \%$ of cooperatives, between 3-9 for $43 \%$ and less than 3 for $10 \%$ (Table2).

A current ratio above 1 for most cooperatives is an indication of their solvency and can readily cover their liabilities adequately. The acid test translates the degree of liquidity of cooperatives. From the table it can be easily deciphered that $40 \%$ had acid test above 15, 27\% between 3-6, $17 \%$ between 6-9. These results are indications of a good liquidity position of cooperatives. They could easily meet unexpected need for cash. The debt to assets ratio of most cooperatives $(53 \%)$ was less than $0.11,23 \%$ had it between $0.11-0.20$ and $13 \%$ had it between 0.31 and 0.40 . Therefore all cooperative societies are highly solvent as assets can easily take care for debts.

The equity to assets shows the proportion of firm's assets financed by owner's equity. It is a comparison of two positive elements of a company. Most cooperatives (43\%) presented ratio between 0.71 and $0.80,20 \%$ between 0.61 and 0.70 while $17 \%$ had it below 0.51 . It means that cooperative societies' equity can finance a good proportion of cooperatives' assets. The current debt to equity ratio is the proportion of current debt that can be financed on cooperative equity. Table 2 results indicate that $43 \%$ of cooperatives also had a ratio of less than $0.11 ; 36 \%$ had a ratio of $0.11-0.20$. These results show that cooperative had enough equity to cater for their debt. In order words most cooperatives had not over borrowed since this ratio is less than 0.5. i.e. not indebted to external bodies. 
The total debt to cooperative equity which is the relative proportion of member-patrons' equity and debt used to finance cooperative assets, was between $1.31-1.40$ for $40 \%$ of cooperatives, 1.51 and above for $23 \%$ of cooperatives and between 1.21-1.30 for $13 \%$ only. As a leverage ratio that compares firm's total liabilities to shareholders' equity showing to what extent owner's equity can cushion creditor's claims in the event of liquidation, the results seem to indicate that though cooperatives are not indebted to outside bodies, these are inwardly. That is, their equity goes more into member's loans than assets.

Table 2. Cooperatives financial ratios analysis.

\begin{tabular}{|c|c|c|c|}
\hline & Range & Frequency & Percentage \\
\hline \multirow{7}{*}{$\begin{array}{l}\text { Current } \\
\text { ratio }\end{array}$} & $\leq 3.1$ & 03 & 10.00 \\
\hline & $3.1-6.0$ & 06 & 20.00 \\
\hline & $6.1-9.0$ & 07 & 23.30 \\
\hline & $9.1-12.0$ & 00 & 00.00 \\
\hline & $12.1-15.0$ & 02 & 06.70 \\
\hline & $15.1 \leq$ & 12 & 40.00 \\
\hline & Total & 30 & 100.00 \\
\hline \multirow[t]{7}{*}{ Acid test } & $\leq 3.1$ & 03 & 10.00 \\
\hline & $3.1-6.0$ & 08 & 26.70 \\
\hline & $6.1-9.0$ & 05 & 16.70 \\
\hline & $9.1-12.0$ & 00 & 00.00 \\
\hline & $12.1-15.0$ & 02 & 06.70 \\
\hline & $15.1 \leq$ & 12 & 40.00 \\
\hline & Total & 30 & 100.00 \\
\hline \multirow{7}{*}{$\begin{array}{l}\text { Debt to } \\
\text { assets }\end{array}$} & $\leq 0.11$ & 16 & 53.30 \\
\hline & $0.11-0.20$ & 07 & 23.30 \\
\hline & $0.21-0.30$ & 01 & 03.30 \\
\hline & $0.31-0.40$ & 04 & 13.30 \\
\hline & $0.41-0.50$ & 01 & 03.30 \\
\hline & $0.51 \leq$ & 01 & 03.30 \\
\hline & Total & 30 & 100.00 \\
\hline \multirow{7}{*}{$\begin{array}{l}\text { Equity to } \\
\text { assets }\end{array}$} & $\leq 0.51$ & 05 & 16.70 \\
\hline & $0.51-0.60$ & 02 & 06.70 \\
\hline & $0.61-0.70$ & 06 & 20.00 \\
\hline & $0.71-0.80$ & 13 & 43.30 \\
\hline & $0.81-0.90$ & 03 & 10.00 \\
\hline & $0.91 \leq$ & 01 & 03.30 \\
\hline & Total & 30 & 100.00 \\
\hline \multirow{7}{*}{$\begin{array}{l}\text { Owners' } \\
\text { equity to } \\
\text { assets }\end{array}$} & $\leq 0.51$ & 02 & 06.70 \\
\hline & $0.51-0.60$ & 03 & 10.00 \\
\hline & $0.61-0.70$ & 03 & 10.00 \\
\hline & $0.71-0.80$ & 10 & 33.30 \\
\hline & $0.81-0.90$ & 09 & 30.00 \\
\hline & $0.91 \leq$ & 03 & 10.00 \\
\hline & Total & 30 & 100.00 \\
\hline \multirow{5}{*}{$\begin{array}{l}\text { Current } \\
\text { debt to } \\
\text { equity }\end{array}$} & $\leq 0.11$ & 13 & 43.30 \\
\hline & $0.11-0.20$ & 11 & 36.70 \\
\hline & $0.21-0.30$ & 03 & 10.00 \\
\hline & $0.31<$ & 03 & 10.00 \\
\hline & Total & 30 & 100.00 \\
\hline \multirow{7}{*}{$\begin{array}{l}\text { Debt to } \\
\text { equity }\end{array}$} & $\leq 1.11$ & 01 & 03.30 \\
\hline & $1.11-20$ & 01 & 03.30 \\
\hline & $1.21-1.30$ & 04 & 13.30 \\
\hline & $1.31-1.40$ & 12 & 40.00 \\
\hline & $1.41-1.50$ & 05 & 16.70 \\
\hline & $1.51 \leq$ & 07 & 23.30 \\
\hline & Total & 30 & 100.00 \\
\hline
\end{tabular}

\section{Cooperative's financial performance Index}

The financial performance is how well firms use assets in their operations. It may be in terms of leverage, growth, or declining risk. In this study financial performance is captured using the formula above. The cooperatives' financial performance index varies between $1.0-7.0$. The cooperatives $47 \%$ had index between $3.1-5.0 ; 40 \%$ had between 5.1-7.0 and $13 \%$ only had between 1.0-3.0. (Table3). The performance index shows a distribution skewed towards higher index values. The mean index is 3.7. Therefore cooperative tend in average to perform well in the use of assets.

Table 3. Distribution of cooperatives financial performance index

\begin{tabular}{lll}
\hline \multicolumn{3}{c}{ Cooperatives financial performance index } \\
\hline Range & Frequency & Percentage \\
-3.0 & 04 & 13.30 \\
$3.1-5.0$ & 14 & 46.70 \\
$5.1-7.0$ & 12 & 40.00 \\
Total & 30 & 100.00 \\
\hline
\end{tabular}

\section{Determinants of cooperative financial performance}

A number of cooperative characteristics were selected as determinants of cooperative financial performance including: age of the cooperative, membership size, number of auditors, interest rate adopted, number of employees, number of training, amount invested, number of loans beneficiaries.

Table 4 indicates the results of OLS estimation to find the determinants of cooperative financial performance. The F-test value of 4.87 is an indication of a significant regression. The adjusted $\mathrm{R}^{2}$ of 0.517 means that selected variables explain $52 \%$ of variability in the dependent variable, the cooperative financial performance index.

Of all variables only cooperative membership size was not significant. The interest rate, number of training undergone, number of management staff, amount invested and number of auditors influence positively cooperative financial performance. Meanwhile number of loan beneficiaries and age of cooperative influence it negatively. Increasing interest rate by 1 unit improves performance by $16 \%$. Cooperative therefore can still increase the level of interest rate applied as this is yet at optimum. Increasing training of staff by 1 unit improves performance by $65 \%$. Regular training of staff is therefore a good factor for improving cooperative financial performance. Performance also increases by $22 \%$, $195 \%$ and $54 \%$ if number of employees, amount invested and number of auditors increase by 1 unit respectively. Therefore cooperatives should strive to keep employment, investment level and number 
of auditors at optimum to ensure greater cooperative performance.

The age and number of loan beneficiaries reduce performance by 40 and $1.5 \%$ respectively. Age of cooperative would indicate greater cooperative mismanagement affecting performance due probably to collusion and sharp practices within the cooperative and the negative effect of loan beneficiaries would indicate a rate of loan delinquency in the cooperatives.

Table 4. Determinants of cooperative financial performance.

\begin{tabular}{llll}
\hline Independent variables & Coefficients & Standard deviation & t- test value \\
\hline Constant & 0.295 & 1.044 & 0.282 \\
Interest rate & 0.162 & 0.089 & $1.820^{*}$ \\
Number of loan beneficiaries & -0.0156 & 0.004 & $-3.638^{* * *}$ \\
Membership size & 0.00079 & 0.001 & $0.893^{\mathrm{NS}}$ \\
Number of training & 0.654 & 0.303 & $2.158^{* *}$ \\
Number of employees & 0.224 & 0.120 & $1.859^{*}$ \\
Amount invested (N) & $1.958 \mathrm{e} 07$ & 0.000 & $2.016^{* *}$ \\
Age of cooperatives & -0.408 & 0.155 & $-2.622^{* *}$ \\
Number of auditors & 0.542 & 0.187 & $2.905^{* * *}$ \\
\hline
\end{tabular}

$\mathrm{R}^{2}=0.517 \quad \mathrm{~F}=4.873 * * *$

$* * * ; * * *$ : test significant at $1 \% ; 5 \%$ and $10 \%$ respectively.

\section{Conclusion and Recommendation}

The results indicate a good financial position of cooperatives with appreciable minimum equity to assets (not less than 0.50) and acid test; an indication of a good liquidity position that may guide against risk. The solvency adjudges cooperatives in the area as potential contributors to community economy. It is also an indication that cooperatives apply good cooperative financial management principles; a probable impact of training received. On performance it is therefore advisable that cooperatives watch their loans policy and old cooperative requires closer supervision to improve financial performance.

In recommendation: i) the interest rate on loan should be kept at a bearable level for members seeking for loan. ii) The number of members obtaining loans should not be more than the range each cooperative can conveniently cope with. iii) Members requesting for loans should be encouraged to use such loans for productive purposes. iv) Constant and regular training sessions should be organized for members and management staff of the cooperatives. i.e. in form of seminars and refresher courses. v) Cooperatives should increase the size of their management staff and employ workers at optimum level to improve efficiency. vi) New and young members should be encouraged to join cooperatives so as to help reduce the negative effect of ageing and familiarity that results into decreasing efficiency. vii) As many auditors as possible should be made to see the proper documentation and appropriation of the cooperative statements of accounts for financial accuracy and efficient financial management.

\section{References}

Adegeye, A. J. \& Dittoh, J. S. (1985). Essentials of agricultural economics. Impact Publishers Nig. Ltd. Ibadan, Nigeria.

Adesina, D. (1998). Essential Information on cooperative credit societies (CTCS \& CICS). Retrieved from: www.worldcat.org

Akridge, J. T. \& T. W. Hertel (1992). Cooperative and investorowned-firm efficiency: A multiproduct analysis. Journal of Agricultural Cooperation. 71-14.

Gittinger, J. P. (1992). Economic analysis of agricultural project. $2^{\text {nd }}$ ed. The John Hopkins University Press. Baltimore Marshall, USA.

Ijere, M. O. (1978). New trends in African cooperatives: The Nigerian Experience. Fourth Dimension Publishers.

Kassali, R. \& R. Adeyemo (2007). Structure-conductperformance of rural cooperatives in Osun State, Nigeria. Bowen Journal of Agriculture. 4(1), 10-21.

Lerman, Z. \& Fulton, J. (1990). A performance of cooperatives and investor owned firms in the dairy industry. Journal of Agricultural Cooperatives. 6,10-22.

Mellor, J. W. (1980). The economics of agricultural development. Cornell University Press, Ithaca and London.

Okeya, I.O.S. \& Adediran, A. T. (1996). Practice of bankingcredit and marketing for professionals. Deji Press and Publishing Co. Nigeria.

Roy, E. P. (1981). Development principles and management of cooperatives. The Interstate Printers and Publishers, Inc. Illinois, USA.

Schrader, L.; E. M. Babb; R. D. Boynton \& M. G. Lang (1985). Cooperative and proprietary agribusiness: Comparison of performance. Research Bulletin 982, Purdue University, Agricultural Experiment Station, West Lafayette, Indiana.

Sexton, R. J. \& Iskow, J. (1993). What do we know about the economic efficiency of cooperatives? An evaluative survey Journal of Agricultural Cooperation. 23, 122-166.

Stevens, R. D. \& Jabara, C. L. (1988). Agricultural development principles. economic theory and empirical evidence. The John Hopkins University Press. Baltimore and London. 